OLIVERA ILIĆ

Institute of Archaeology,

Belgrade, Serbia

o.ilic@ai.ac.rs

EMILIJA NIKOLIĆ

Institute of Archaeology,

Belgrade, Serbia
930.85:27(497.11)"2013"

338.485:902/904(497.11)

711.52:902

COBISS.SR-ID 219301132

Original research article

Received: May $27^{\text {th }} 2015$

Accepted: November $15^{\text {th }} 2015$

\title{
ARCHAEOLOGICAL PARK VIMINACIUM: CULTURAL-HISTORICAL HERITAGE IN THE JUBILEE YEAR OF CHRISTIANITY*
}

\begin{abstract}
In the Jubilee year when the Christian world celebrated 17 centuries since the signing of the Edict of Tolerance - the Edict of Milan, through the proclamation of which, in 313 in Milan, Emperor Constantine the Great allowed religious equality and stopped the persecution of Christians, the Archaeological Park Viminacium, was actively involved in a program to mark this important anniversary with two events, actually important national exhibition and famous Verdi's opera Aida. Those events attracted thousands of visitors and again marked the Archaeological Park Viminacium as one of the most important and most successful promoters of cultural and historical heritage in Serbia. In future, we hope that tourism in this area, based on rich cultural and historical heritage will be more developed, using Viminacium as a leader and a model.
\end{abstract}

KEYWORDS: EDICT OF MILAN, EXHIBITION, OPERA, THE VIMINACIUM ARCHAEOLOGICAL PARK, CULTURAL-HISTORICAL HERITAGE.

\section{EXHIBITION}

One of the central events which marked the seventeen centuries since the official recognition of Christianity was the exhibition Constantine the Great and the Edict of Milan 313. The birth of Christianity in Roman provinces in the territory of Serbia, organised by the National Museum in Belgrade. It was initially displayed in the exhibition rooms of the building Domus Scientiarum Viminacium - Archaeological scientific and research centre, at the Archaeological Park Viminacium ${ }^{1}$ (Fig. 1, 2), before moving to the atrium of the National Museum in Belgrade, concluding in Niš, the birthplace of Constantine the Great. ${ }^{2}$

1 About the building Domus Scientiarum Viminacium - Archaeological scientific and research centre, see in: Nikolić, 2012 and Nikolić, 2014a.

2 This exhibition is accompanied by a luxury published catalog in which preparation involved numerous authors, experts in different fields of Roman archeology. Editors of the publication are Bojana Borić Brešković and Ivana Popović, who are also the main organizers of the exhibition.

*The article results from the project: IRS - Viminacium, Roman city and military legion camp - research of the material and non material culture of inhabitants by using the modern technologies of remote detection, geophysics, GIS, digitalisation and $3 D$ visualisation (no 47018), funded by the Ministry of Education, Science and Technological Development of the Republic of Serbia. 


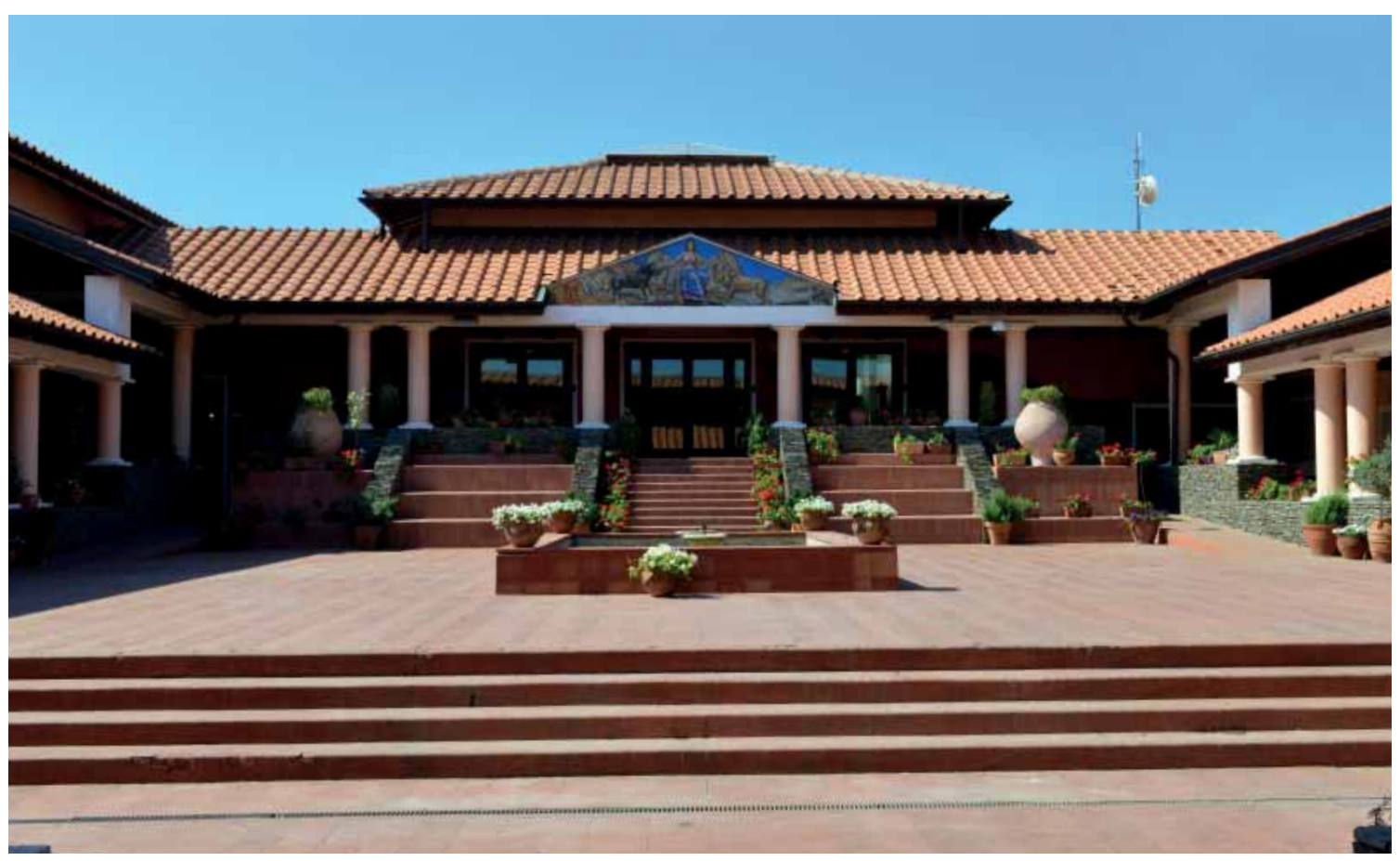

Fig. 1 Archaeological park Viminacium, Domus Scientiarum Viminacium.

(Photo-documentation of Institute of Archaeology, Belgrade)

The exhibition was divided into several thematic parts which covered several periods: before the Tetrarchy, the Tetrarchy and the period of the rule of Constantine the Great and his successors. The richness of life in the urban centres of the Roman provinces of the territory of the Central Balkans was represented by items of gold, silver and bronze which are archaeological finds from the residential complexes of Sirmium, Mediana, Romulina, Šarkamen etc. More than 180 artefacts were on display, produced between the $2^{\text {nd }}$ century $\mathrm{AD}$ and the time of Constantine's successors in the period of Late Antiquity. They represented archaeological items found in the territory of Serbia which have been preserved in museums. Among the displayed items (sculptures, fragments of architectural decoration, frescoes, mosaics, jewellery, silver dishes, parts of military equipment and Roman imperial coins), there were several artefacts of exceptional value such as a helmet from Berkasovo in Vojvodina, imperial jewellery from Šarkamen in eastern Serbia, a cameo from Kusadak (Fig. 3) etc.

As an introduction to the time that preceded
Constantine's epoch, the exhibition included jewellery from the end of the $2^{\text {nd }}$ and the $3^{\text {rd }}$ century $\mathrm{AD}$, parade armour and a pectoral from Ritopek (Castra Tricornia), organ pipes from Golubac (Cuppae), two sceptres, made of wood and gilded silver, from Dubravica (Margum) and Kostolac (Viminacium), as well as items of luxury silver ware which were sourced from the major mining centres of the mountains Rudnik and Kosmaj.

What is specific to the territory of Serbia is the number of items from the period of the Tetrarchy. Galerius and Maximinus Daia and later Constantine the Great left an indelible mark on this region with the construction of the imperial residential complexes in Romuliana (Gamzigrad), Šarkamen, and Mediana (Brzi Brod). Consequently, this period occupied a significant place in the exhibition with displayed busts of tetrarchs carved out of porphyry from Niš (Naissus), Gamzigrad (Romuliana) and Tekija (Transdierna) and pilasters with the busts of tetrarchs from Romuliana, as well as the famous gilded bronze bust of Constantine the Great (Fig. 4). Among some extremely valuable exhibits was a set of women's gold jew- 


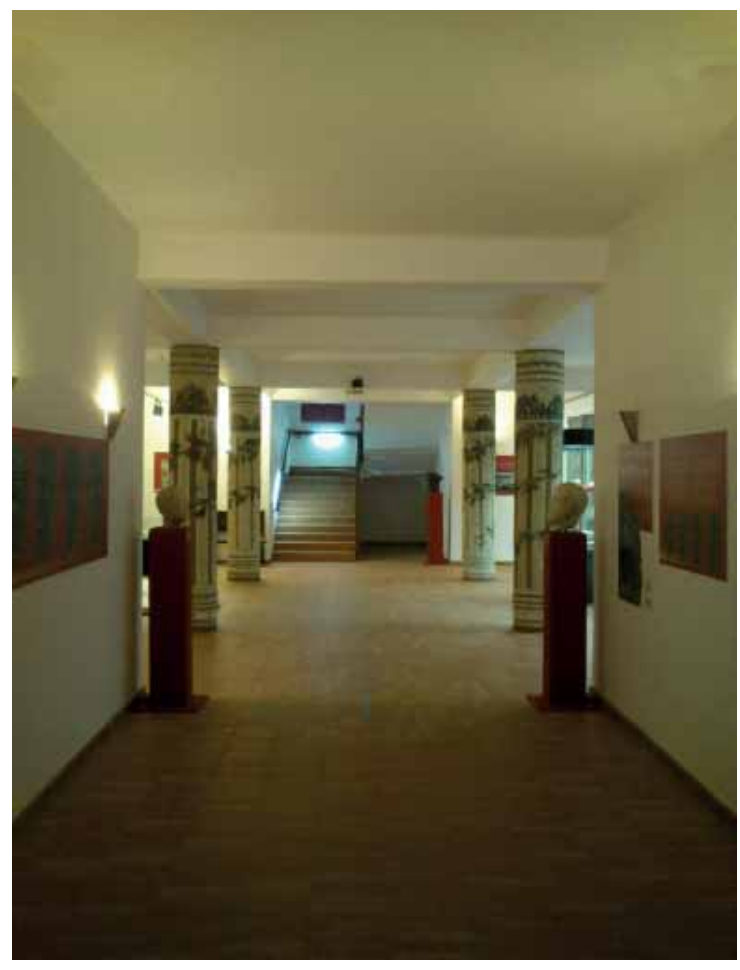

Fig. 2 Archaeological park Viminacium, Domus

Scientiarum Viminacium - the exhibition rooms. (Photo-documentation of Institute of Archaeology, Belgrade)

ellery from the mausoleum in Šarkamen, which some authors assumed to belong to the mother of the emperor Maximinus Daia (Popović, Tomović 1998) and a silver jubilee plate (phialla) made in the imperial workshops in Niš (Naissus officina) to commemorate the tenth anniversary of the reign of the emperor Licinius, in $316 \mathrm{AD}$. Constantine's vicennalia in $326 \mathrm{AD}$ was the occasion to officially reward individuals for their services.

In the part of the exhibition dedicated to religion were items related to the traditional Roman gods, among which should be noted a votive porphyry sculpture of Asclepius and Hygeia, and a marble sculpture of a deity of the Dardanians, identified as Dea Dardanica, from the residential complex at Mediana, Heracles with Telephus from Singidunum, sculptures of genius of spring and winter from Singidunum (Fig. 5). In addition to the cult of classic Roman deities, from the $2^{\text {nd }}$ century AD there was growing interest in Oriental deities whose cults spread with the arrival of

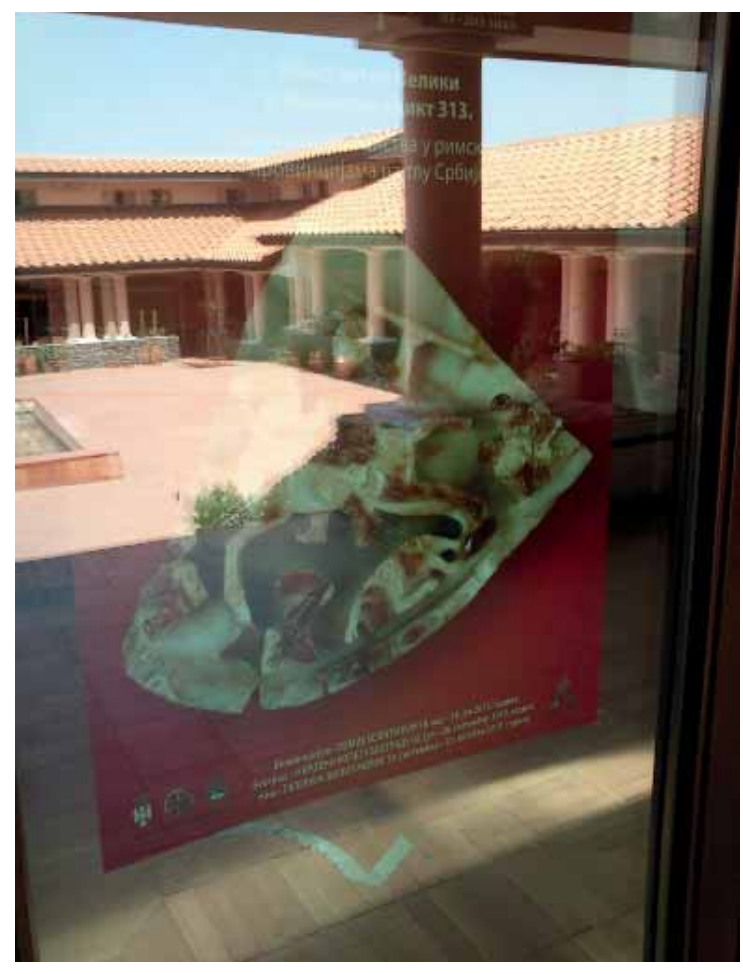

Fig. 3 Cameo from Kusadak (poster of the exhibition). (Photo-documentation of Institute of Archaeology, Belgrade)

the army and traders from the East. In the exhibition they were represented by the cult emblem of Jupiter Dolichenus in gilded bronze from the sanctuary at Brza Palanka (Egeta), a lead icon of a Danubian Horseman from the vicinity of Šabac and a marble relief of the god Mithras from Smederevo (Vinceia).

This part of the exhibition was followed by showcases displaying objects that carry Christian symbolism, suggesting the process of the spread of Christianity and the freedom of religious confession allowed by the Edict of Milan. Sirmium, as the administrative, commercial and cultural centre of the province of Pannonia Secunda, became one of the official residences of the Roman Emperors in the period of Late Antiquity. It was also the city of Christian martyrs. The importance of the city was confirmed by architectural sculptures, including a significant number with Christian characteristics. Naissus was also a significant Christian centre as evidenced by the numerous re- 


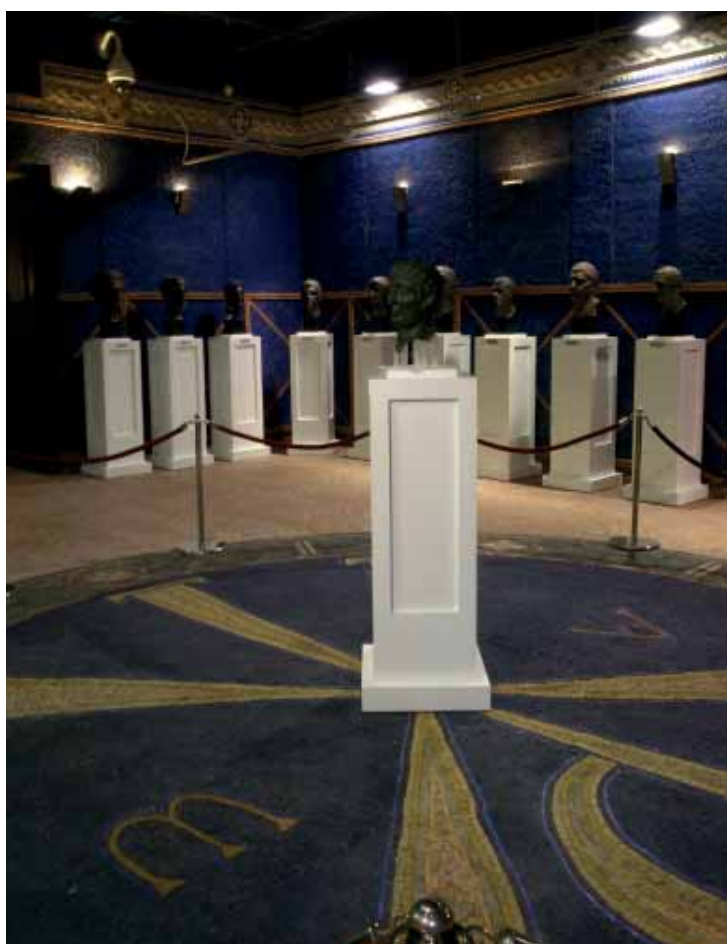

Fig. 4 Pilasters with the busts of Roman emperors; in the centre the famous gilded bronze bust of Constantine the Great. (Photo-documentation of Institute of Archaeology, Belgrade)

mains of sacred objects that point to the Christian commitment of a substantial part of the residents of the ancient city.

Showcased exhibits that bear a Christian message and symbolically portray Constantine's legacy in religion included a silver reliquary from Gamzigrad (Romuliana), a blessing hand made of ivory, from Caričin Grad, an elegant deep silver bowl with an engraved Greek cross from Niš (Naissus), silver footed goblets with lids and silver spoons from Viminacium, a jug made of bronze from Kostol (Pontes) and a gold necklace with medallions and a pendant shaped as a cross from Višnjica (Ad Octavum) (Fig. 6, 7).

It should be mentioned that there was a whole section at the exhibition dedicated to the Roman army, which was represented by several exceptional exhibits such as a helmet from Jarak and a parade helmet from Berkasovo which were displayed together with a cruciform fibulae (Fig. 8, 9).

The everyday life of the Roman population in today's Serbia during the Late Antique period was

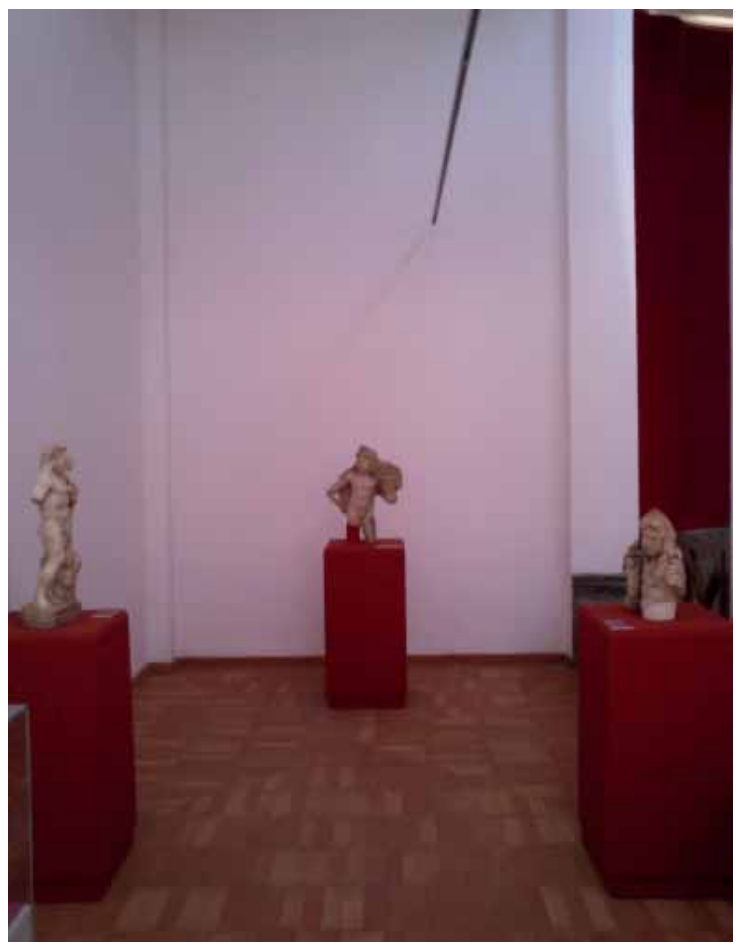

Fig. 5 Sculptures of genius of spring and winter from Singidunum. (Photo-documentation of Institute of Archaeology, Belgrade)

revealed by ceramic and glass vessels, as well as the luxurious silver vessels from Naissus and $\mathrm{Vi}$ minacium, reflecting the taste of the Roman aristocracy.

Finally, we should mention the section of the exhibition which contained valuable numismatic finds.

Bearing in mind the representativeness of the displayed museum exhibits, we could say that this exhibition was of great importance not only for experts, but also for the general public, since it was the first time that the entirety of the representative antique archaeological material from the territory of Serbia had been presented. This exhibition was a major undertaking that will be remembered as a great cultural event in Serbia, contributing to the general celebration of this important date in the entire Christian world. 


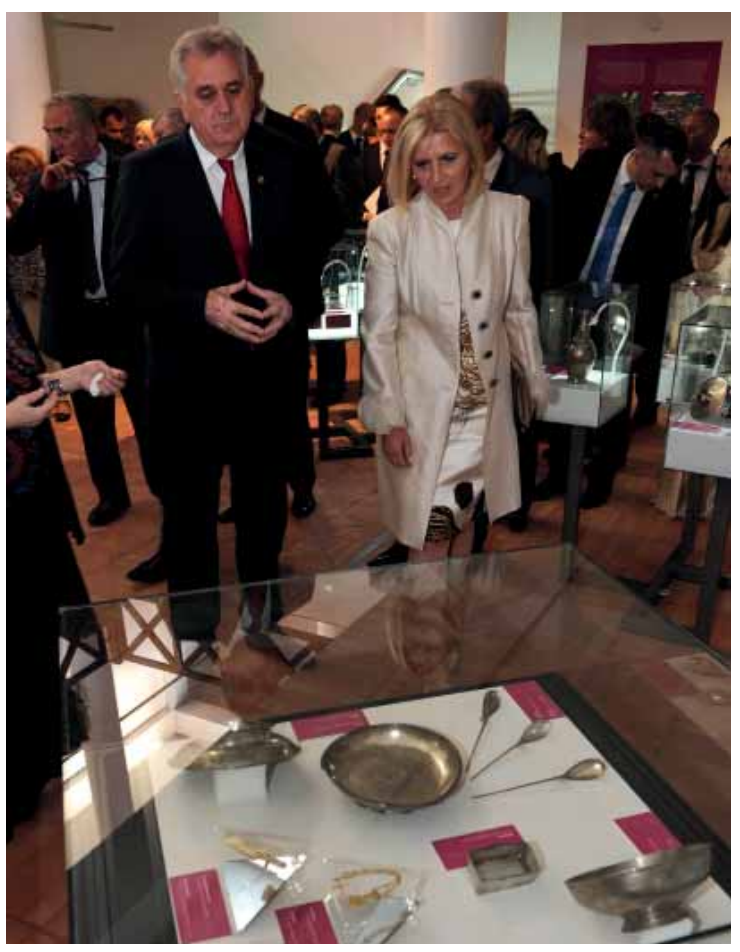

Fig. 6 Silver dishes and spoons with Christian features. (Photo-documentation of Institute of Archaeology, Belgrade)

\section{OPERA}

In addition to the exhibition, 1700 years of the Edict of Milan was marked by another exceptional event, Verdi's opera Aida, performed by the ensemble of the National Theatre of Belgrade.

The musical and theatrical spectacle, as a part of the state program of marking 17 centuries of the Edict of Milan, was solemnly opened by the Ambassador of Italy in Serbia, Armando Varricchio, who was the host of the evening. The Embassy of Italy donated the performance of Aida at Viminacium to the state project of marking the Edit of Milan.

The masterpiece of the famous Italian composer Giuseppe Verdi's Aida was performed in the Roman amphitheatre of Viminacium, reconstructed for this occasion, ${ }^{3}$ under a starry sky in the attendance of approximately 2000 visitors (Fig. 10, 11).

The newly reconstructed amphitheatre has become the biggest attraction of the archaeological

3 About the amphitheatre reconstruction, see in $\mathrm{Ni}$ kolić 2014b. site of Viminacium. It is important to mention that this is the only excavated and presented Roman amphitheatre in Serbia. It is a place with all the necessary facilities for both visitors and actors and performers, having a large auditorium as well as a reception hall and changing rooms.

With the protection and presentation of the amphitheatre, Project Viminacium is following the modern processes of sustainable development, whereby the revitalisation of historic buildings is a key factor (Fig. 12, 13). It is hoped that the Viminacium amphitheatre will become an important space for all kinds of modern performances, concerts and sporting events, as well as a setting for summer theatre or film festivals.

\section{CONCLUSION}

These events were some of the numerous activities of the Archaeological Park Viminacium, many of which have enjoyed substantial support from the Kostalac power-plant. Through the joint activities of the Archaeological Park Viminacium and the Kostalac power-plant, it has been possible to create a unique cultural landscape that has resulted in a combination of cultural and natural resources, an area that shows how two seemingly opposing activities - the preservation of cultural heritage and the rapid development of industry - can work together for decades (Fig. 14). ${ }^{4}$ With the regular and planned maintenance of such landscapes, they can become the basic accelerators of the social and economic development of the local population and even the region as a whole. In the future, when the mining and energy sectors cease to be the carriers of local development, tourism based on a rich cultural-historical heritage will be able to offer new opportunities to this area (Fig. 15).

Today cultural and archaeological tourism is gaining more importance especially in countries with numerous preserved archaeological mon-

4 About this see in: E. Nikolić, O. Ilić and D. Rogić 2013. 


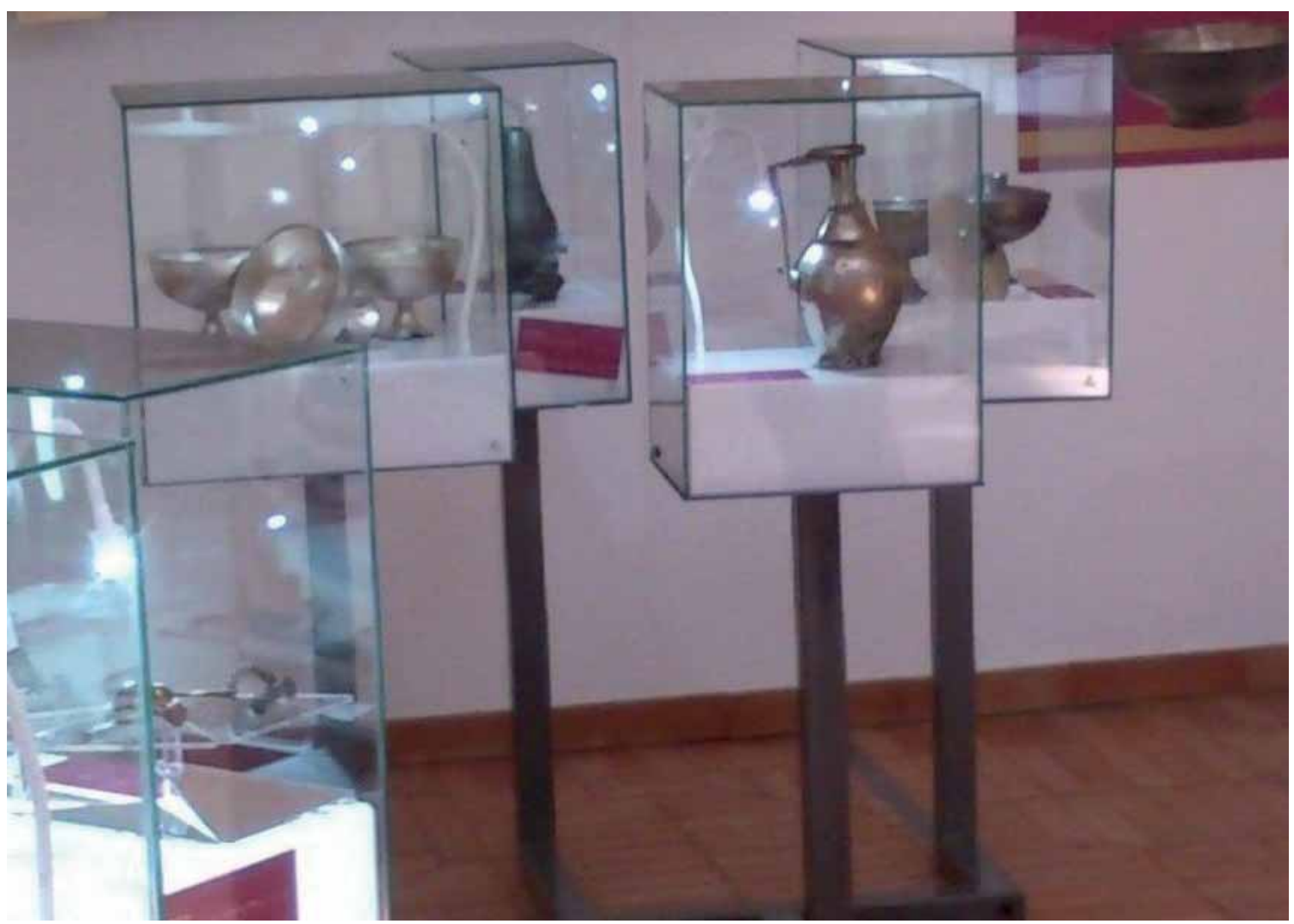

Fig. 7 Silver dishes with Christian features.

(Photo-documentation of Institute of Archaeology, Belgrade)

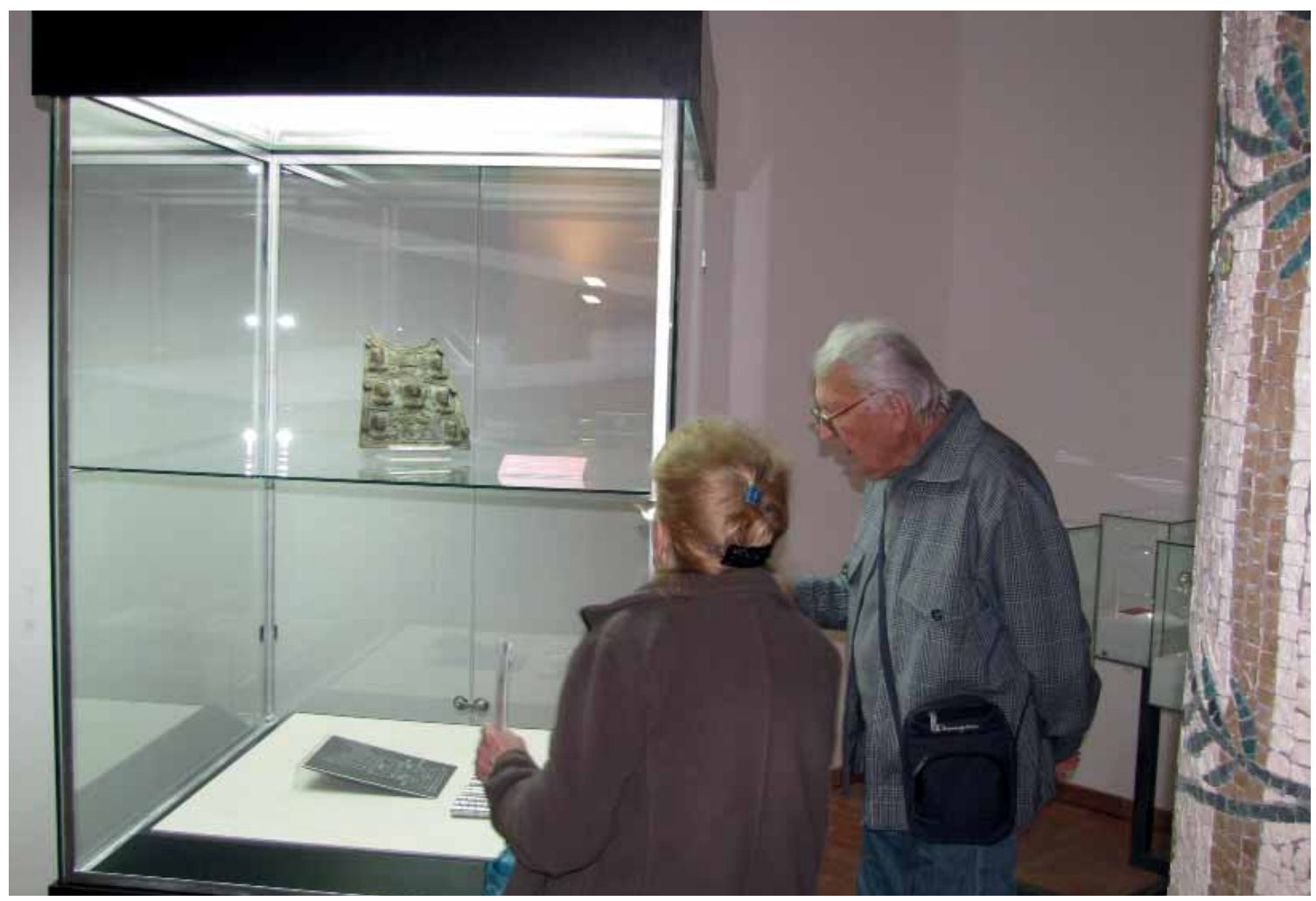

Fig. 8 Pectoral from Ritopek.

(Photo-documentation of Institute of Archaeology, Belgrade) 


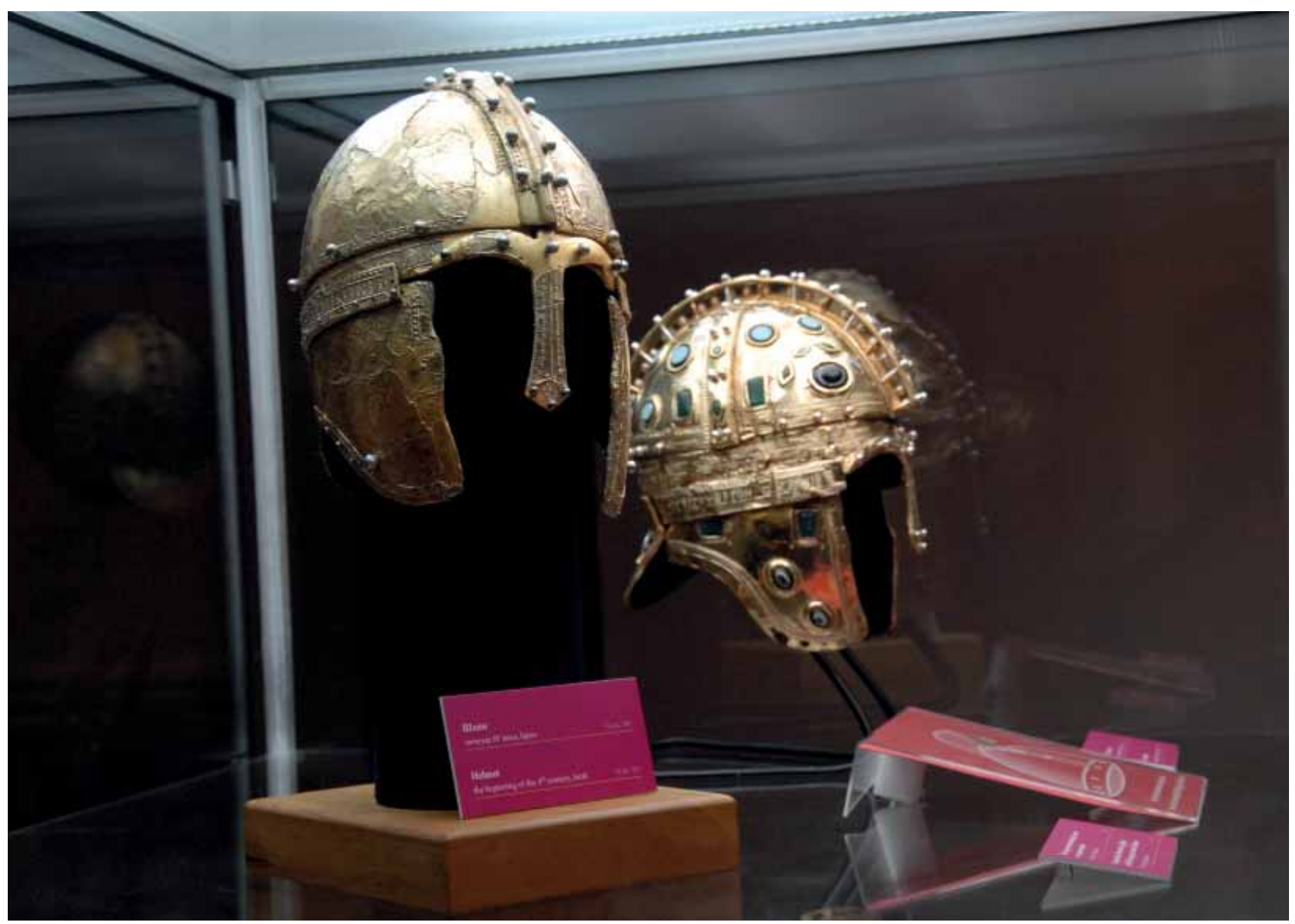

Fig. 9 Luxuriously decorated helmets encrusted with gold foil from Berkasovo. (Photo-documentation of Institute of Archaeology, Belgrade)

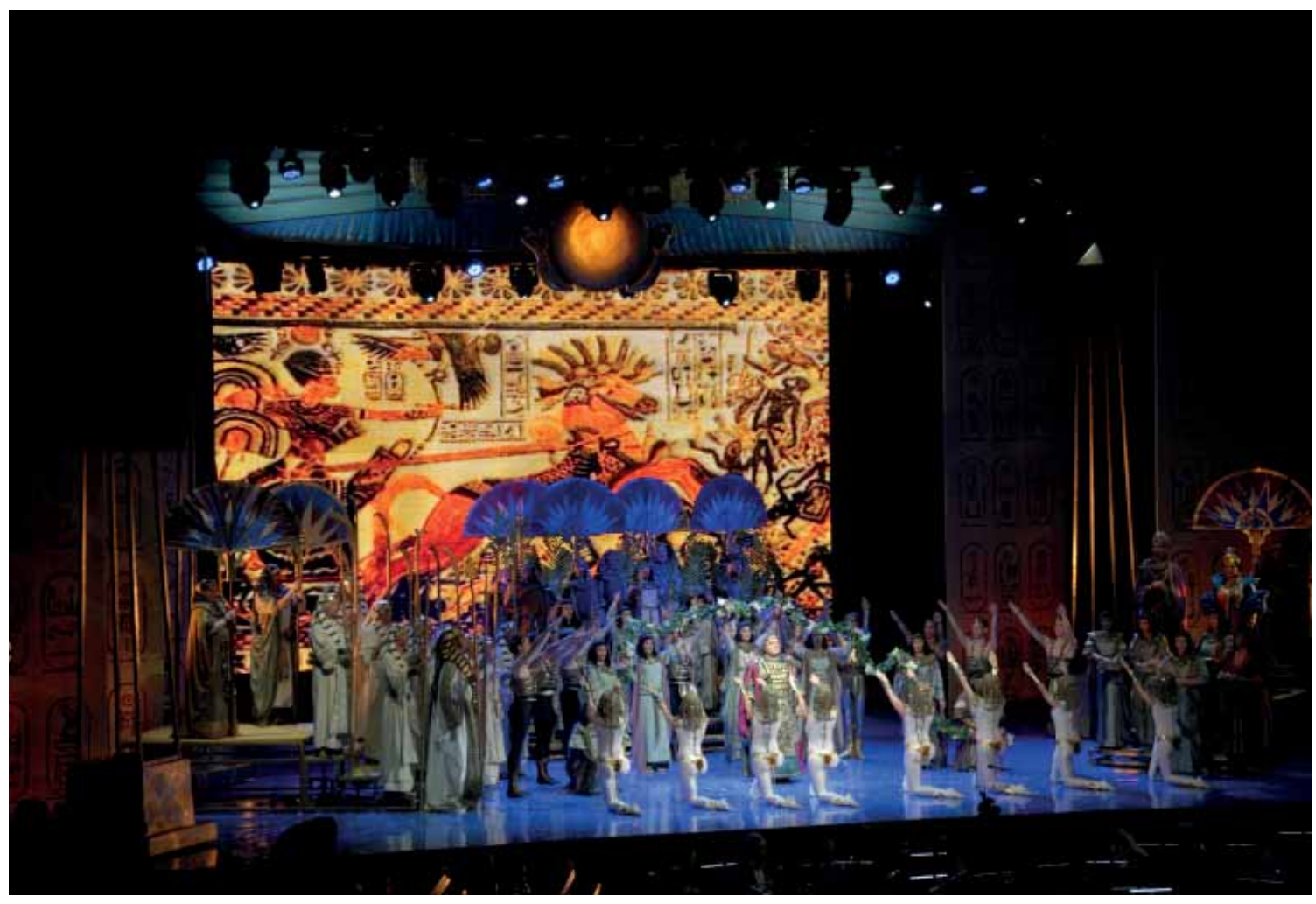

Fig. 10 Verdi's opera Aida in reconstructed Roman amphitheatre of Viminacium.

(Photo-documentation of Institute of Archaeology, Belgrade) 


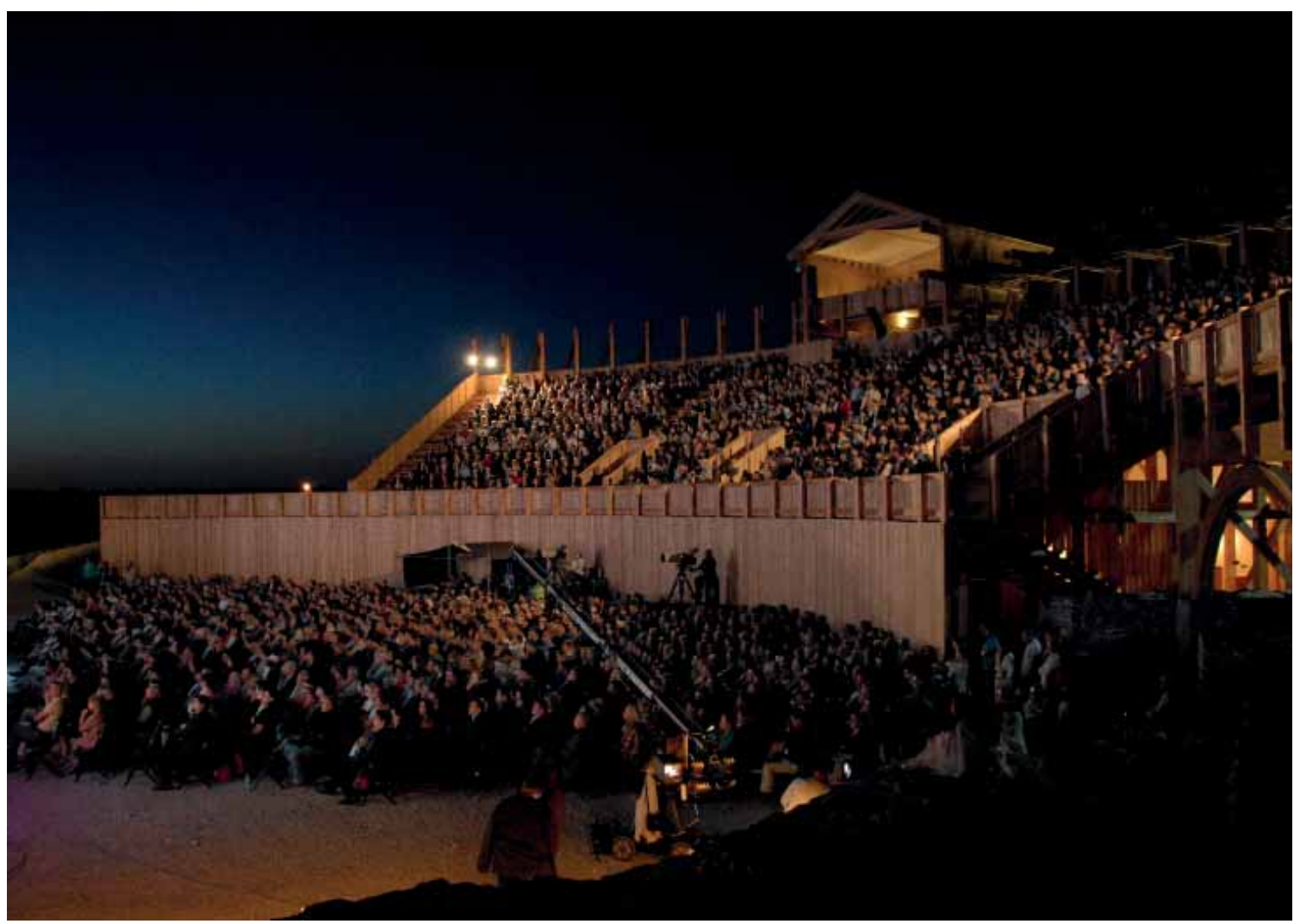

Fig. 11 Reconstructed Roman amphitheatre of Viminacium.

(Photo-documentation of Institute of Archaeology, Belgrade)

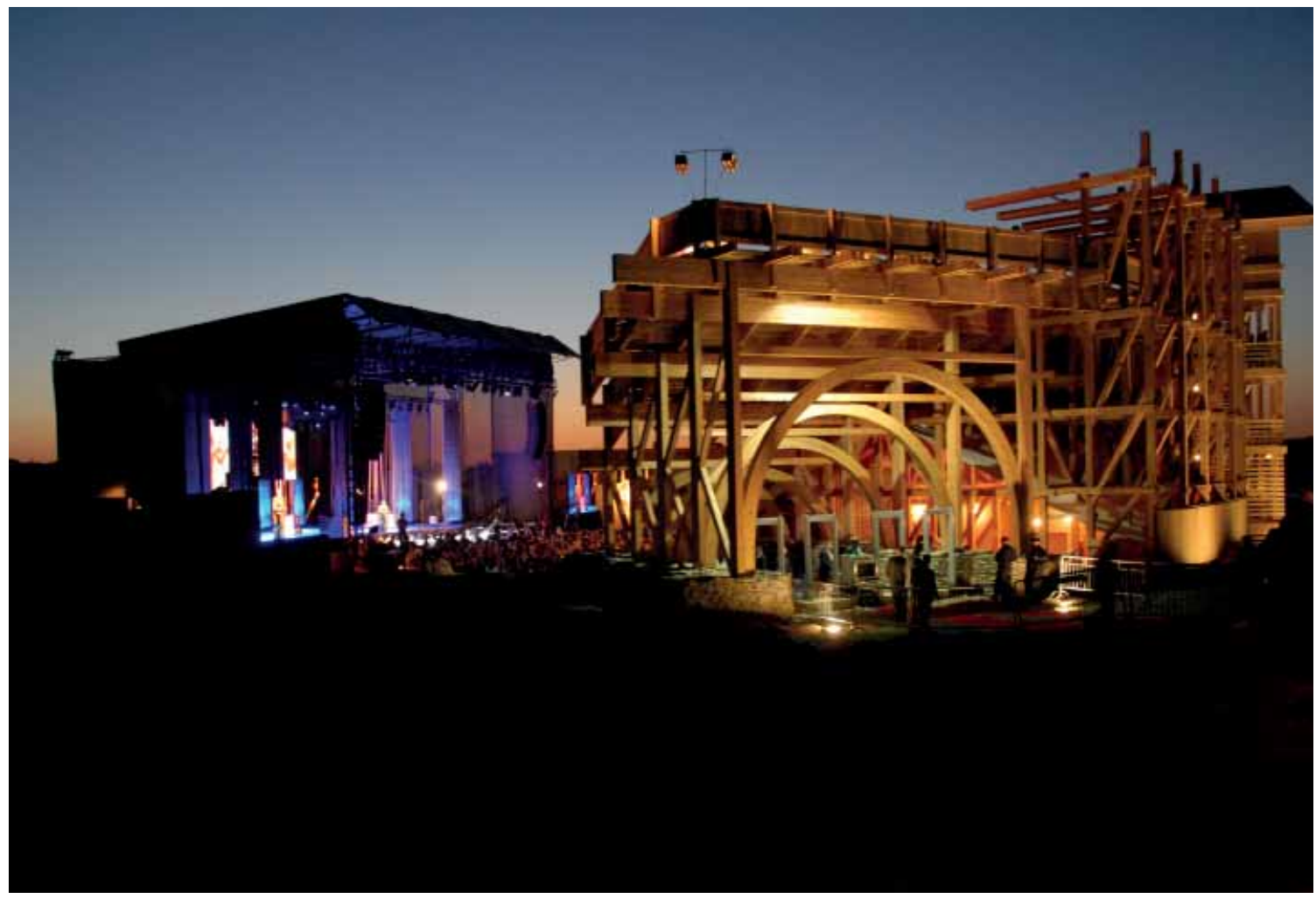

Fig. 12 Reconstructed Roman amphitheatre of Viminacium.

(Photo-documentation of Institute of Archaeology, Belgrade) 


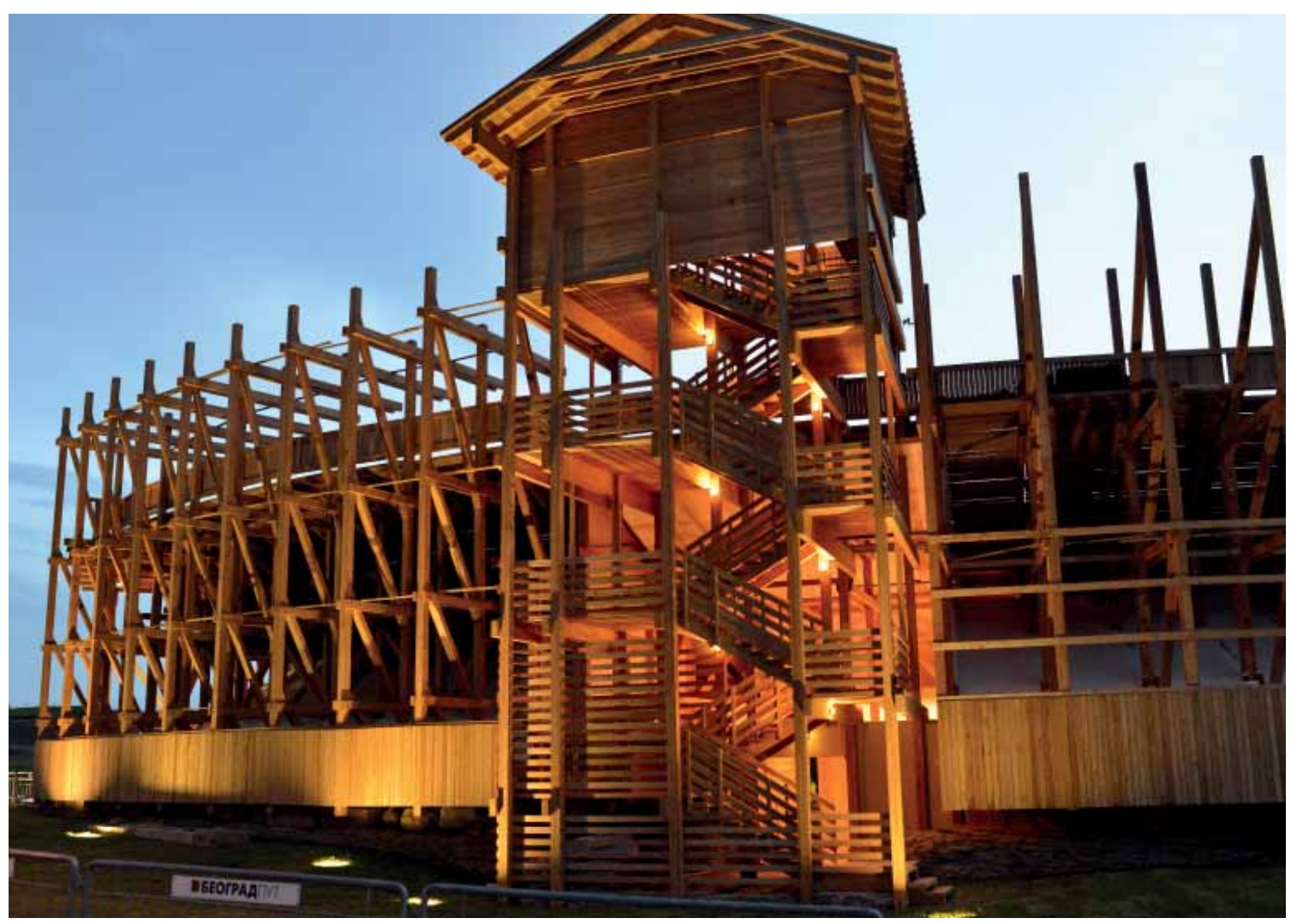

Fig. 13 Reconstructed Roman amphitheatre of Viminacium.

(Photo-documentation of Institute of Archaeology, Belgrade)

uments among which is also Serbia. The first results show that the Archaeological Park Viminacium has developed into a tourist destination of great importance in recent years, especially since it lies along the cultural-historical road which became part of a tourist project Itinerarium Romanum Serbiae. ${ }^{5}$

As confirmation of these assertions, we can mention the results of a poll among foreign visitors who come to Viminacium on the cruise ships on the Danube. ${ }^{6}$ The visitors positively evaluated park, but also noted all the problems in the surrounding area. All of them submitted encouraging and constructive comments. The whole presentation of the park was rated as a complete, educational experience and a perfect way to preserve history.

5 About this, see in: Korać, Golubović and Mrđić 2009; Korać 2014.

6 About this, see in: Anđelković Grašar, Tapavički-Ilić 2012; Anđelković Grašar, Tapavički-Ilić 2014.
Most of the visitors stated that pollution in the air is a big problem for Viminacium. Some of the visitors expressed a wish to visit this industrial complex, whilst others were interested in the process of archaeological excavation and wished to observe all its phases. Other recommendations came in the form of suggestions of how to improve the offer of the park. These were linked to the sale of souvenirs, but also to easier access for elderly persons, as well as video presentations showing those areas which people with difficulties are unable see. Many positive comments were made regarding the well informed and pleasant guides.

It is interesting to read the blog of one American tourist who wrote “... but Viminacium didn't disappoint me. As I looked over the corn fields, I was reminded of Saint-Exupery's story, The Little Prince, when he landed in the Sahara desert and met the (imaginary) boy prince from another planet. The Little Prince taught him that what is important is often invisible to the eye, such as wa- 

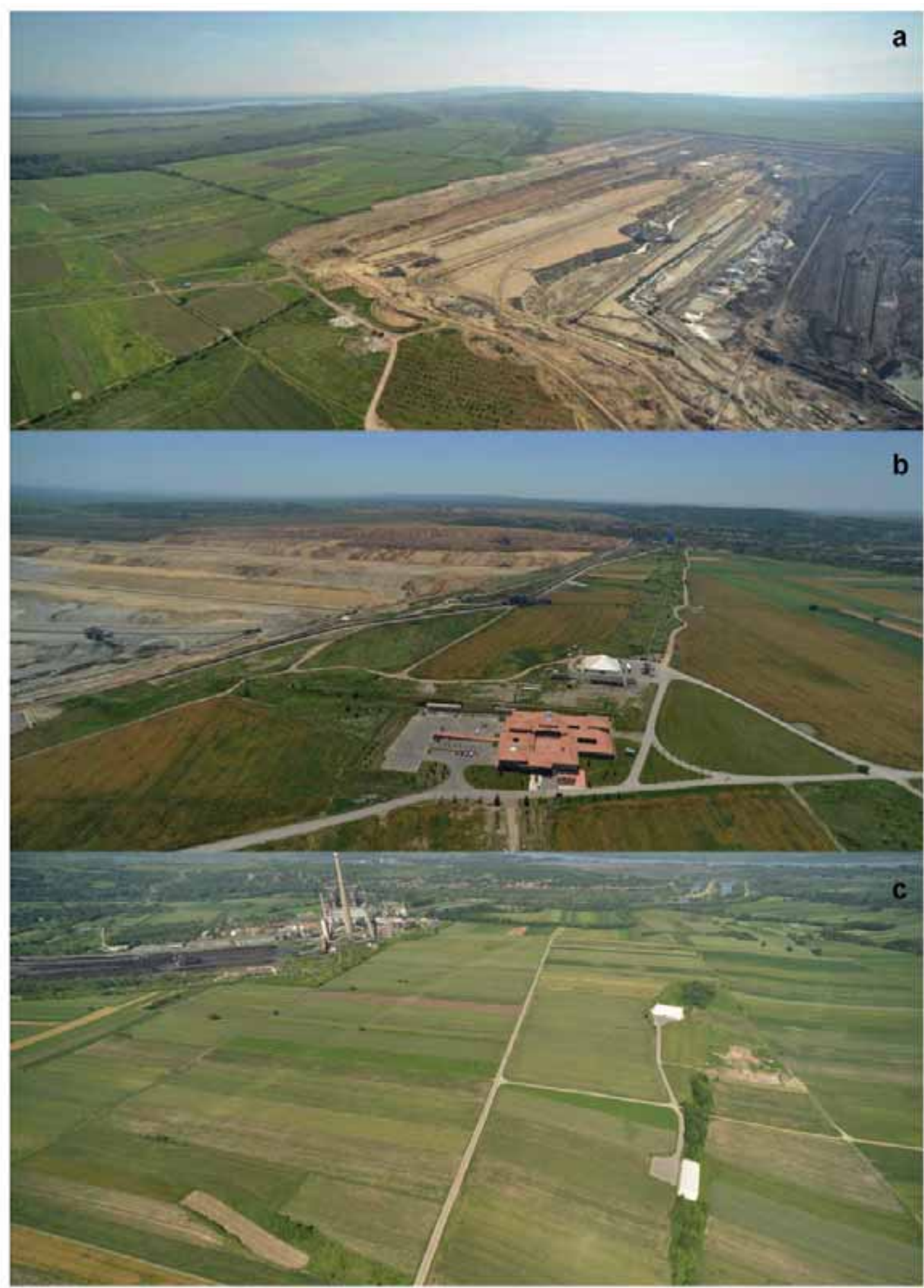

Fig. 14 Natural, civilisational, cultural and historical factors of the landscape.

a. Open pit "Drmno". b. Buildings in the Archaeological park Viminacium and the open pit "Drmno". c. Archaeological park Viminacium, the power plant "Kostolac B", the rivers Mlava and Danube and the village of Stari Kostolac (Nikolić, E., Ilić, O. and Rogić, D. 2013: 266, fig. 7. 


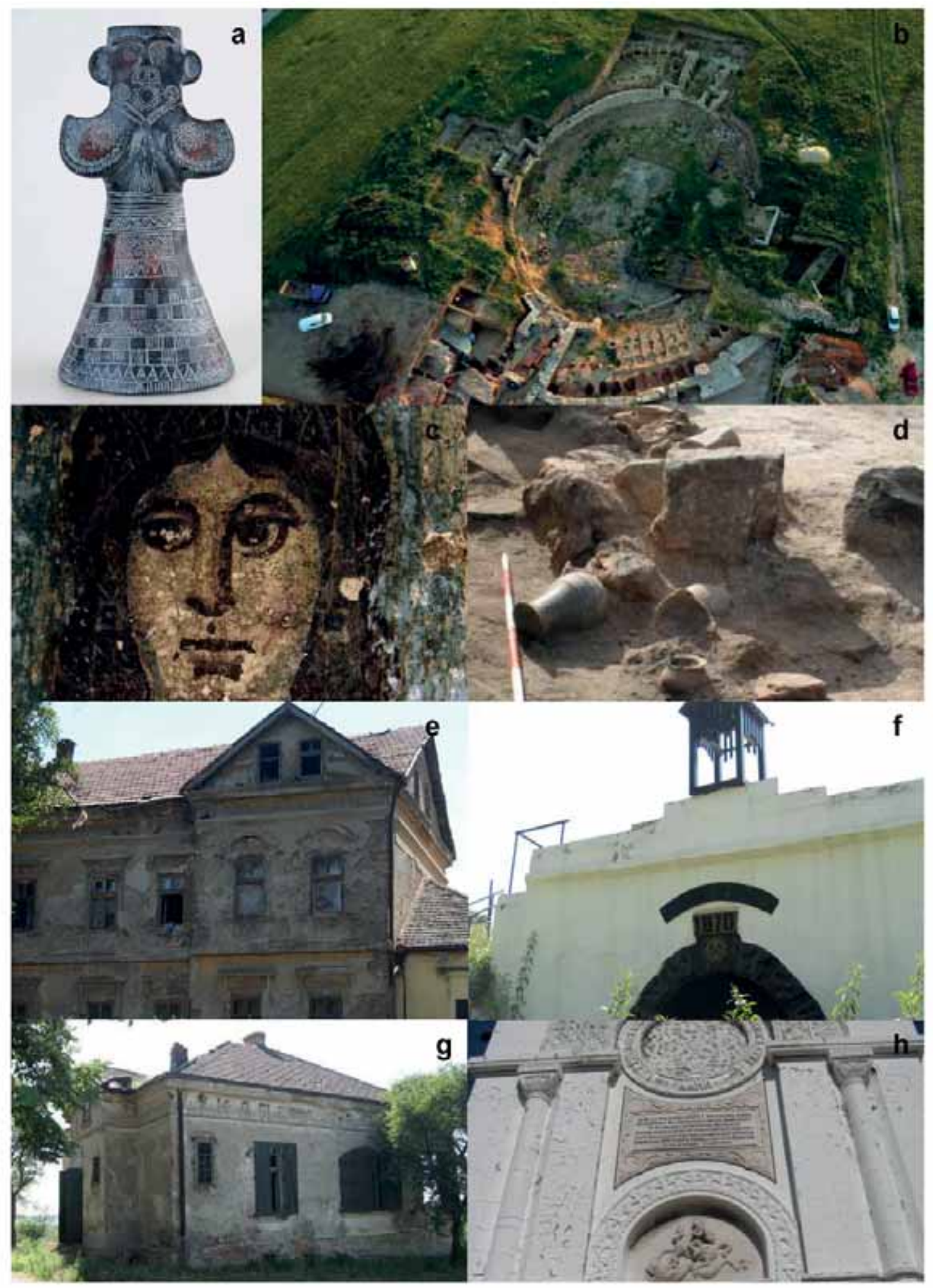

Fig. 15 Cultural and historical factors of the landscape. a. Prehistoric figure named Kličevac idol. b. Viminacium amphitheatre. c. Detail of a fresco from the 4th century found in a tomb in Viminacium. d. Archaeological research of medieval Braničevo. e. Main administrative building of the old mine in the village of Stari Kostolac. $f$. Entrance to the old mine in the village of Stari Kostolac. g. Family villa of the river captain, on the hill above the village of Stari Kostolac. h. The church from 1924, on the hill above the village of Stari Kostolac.

(Nikolić, E., Ilić, O. and Rogić, D. 2013: 262, fig. 3. 
ter hidden somewhere in the desert, and that one must learn to see with one's heart, not just rely on what is seen by the eyes." (The Mystery of Viminacium, Serbia, 2010)

As to the suggestions and comments of domestic and foreign visitors, we can mention entries in the Viminacium Guest Book which has been in place since the opening of the archaeological park. There were some comments emphasising the educational role of Viminacium, such as "History is interesting..." and "Roman times have come alive in front of us..." Also, there were comments speaking of the large impact the park has had on the memories, feelings, experiences and thoughts of visitors. "Excitement, satisfaction, enthusiasm are little compared to what I felt and experienced...”, “...for a moment it was like I had sat in a time machine and gone into past...", “...a special gift for the soul, eyes, body...”, “ ... real magic, mystery...", “... it sent excitement and shivers to my heart...", "... it is so nice to return to the past, the future looks brighter..." (Viminacium Guest Book).

On the basis of this short review, we can conclude that in modern tourism it is very important that a place has its own distinctive spirit that helps to create the experience of the visitors. ${ }^{7}$ With the revitalisation of the Viminacium amphitheatre, started in 2013, one can still feel the spirit of ancient times in an ancient setting, whilst fulfilling modern needs, with the aim to make a building live again, just as it did during the Edict of Milan celebration.

The Domus Scientiarum at Viminacium was designed as a building of ancient composition and themes, with the interweaving of traditional and contemporary building materials whilst, at the same time, a host to modern facilities. (Nikolić 2014a: 185) The motifs and symbols of the mosaic scenes in the exhibition rooms, just like the architectural elements of the massive, heavy, coffered ceiling covered with mosaics and ostensibly

7 More on the topic connected to Viminacium in: Nikolić, Anđelković and Rogić, 2011. carried by the pillars set into the wall, brings mysticity into the space, (Nikolić 2014a:186) a feature that suits a large exhibition, such as the one that, in 2013, celebrated the birth of Christianity.

\section{BIBLIOGRAPHY}

\section{Anđelković Grašar, J. and Tapavički-Ilić, M.} 2014

Senior Visitors, Junior Enthusiasm: Analysis of Visitors, Questionnaire. Archaeology and Sciences 9: 191-204.

\section{Korać, M. 2014}

Pre - feasibility Study Itinierarium Romanum Serbiae. Archaeology and Sciences 9/2013: 9-35.

\section{Korać, M. Golubović, S. and Mrđić, N. 2009}

Itinerarium Romanum Serbiae, Belgrade: Center for New Technologies Viminacium.

The Mystery of Viminacium, Serbia, 2010

http://janetsjaunts.blogspot.rs/2010/11/mystery-of-viminacium-serbia.html

\section{Nikolić, E. 2012}

Putevima razvoja jednog arheološkog parka: Građevina Domvs Scientiarvm Viminacivm, in: Arheološki institut Godišnjak 2011. Godina, (eds.) Vesna Bikić, Snežana Golubović, Dragana Antonović. Beograd: Arheološki institut: 66-68.

\section{Николић, Е. 2014а}

Domus Scientiarum Viminacium: Композиција и детаљи обликовања, Гласник Друштва конзерватора Србије 38: 181-188.

\section{Nikolić, E., Ilić, O. and Rogić, D. 2013}

Posibilities of defining the archaeological site of Viminacium as a unique cultural landscape, in: (eds.) A. Filipović, W. Troiano, Strategie e Programmazione della Conservazione e Trasmissibilita del Patrimonio Culturale, Roma: 260-271. 
Николић, Е. 2014b

Примена кречног малтера приликом рестаурације римског амфитеатра Виминацијума током 2013. године, у: Грађевински материјали и конзерваторско-рестаураторски поступщи - малтери, (ур.) Данијела Младеновић, Елена Васић-Петровић, Београд: Друштво конзерватора Србије: 37-50.

Nikolić, E., Anđelković J. and Rogić, D. 2011 Archaeological Park as a Product of Emotional Design: Design and Organization of a Park Based On the Exploration of Visitors' Emotions, Archaeology and Sciences 6: 259-270.

\section{Popović, I. and Tomović, M. 1998}

Golden jewellery from the Imperial mausoleum at Šarkamen (Eastern Serbia), Antiquité Tardive 6: 287-312.

\section{REZIME}

ARHEOLOŠKI PARK VIMINACIUM - KULTURNO ISTORIJSKO NASLEĐE U JUBILARNOJ GODINI HRIŠĆANSTVA

\section{KLJUČNE REČI: MILANSKI EDIKT, IZLOŽBA, OPERA, ARHEOLOŠKI PARK VIMINACIUM, KULTURNO-ISTORIJSKO NASLEĐE.}

U jubilarnoj 2013. godini kada je čitav hrišćanski svet proslavljao sedamnaest vekova od potpisivanja Edikta o toleranciji tzv. Milanskog edikta, Arheološki park Viminacijum se aktivno uključio u obeležavanju ove proslave. Izložba Konstantin Veliki i Milanski edikt (313), rađanje hrišćanstva u rimskim provincijma na tlu Srbije u organizaciji Narodnog muzeja u Beogradu imala je posebno mesto u proslavi ovog jubileja. Izložba je otvorena u izložbenim prostorijama Domus Scientiarum Viminacium - Arheološkog naučno istraživačkog centra u Arheološkom parku Viminacium, zatim je celokupna postavka izložbe preseljena u atrijum Narodnog muzeja u Beogradu i na kraju je prezentovana u Nišu, rodnom gradu Konstantina Velikog.

Drugi značajan događaj koji je obležio ovaj važan jubilej, bila je opera Aida u izvođenju ansambla Narodnog pozorišta iz Beograda. Čuveno delo italijanskog kompozitora Đuzepe Verdija izvedeno je $\mathrm{u}$ rimskom amfiteatru rekonstruisanom za ovu priliku.

Ovi događaji privukli su brojne posetioce pokazujući da je Arheoški park Viminacium jedan od najznačajnijih i najuspešnih promotera kulturnog i istorijskog nasleđa Srbije. U budućnosti, razvoj turizma u ovoj oblasti, baziran na kulturnom i istorijskom nasleđu, svakako će kao uzor i model imati Arheološki park Viminacium. 